\title{
SALINITY INTRUSION IN THE GUAPIMIRIM ESTUARY, RIO DE JANEIRO STATE, BRAZIL
}

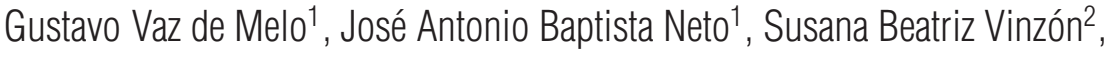 \\ Allan Sandez de Oliveira', Michel Arthur Faria Vicente ${ }^{1}$, \\ Olaf Malm ${ }^{3}$ and Cleverson Guizan Silva ${ }^{1}$
}

\begin{abstract}
This work was conducted in the Guapimirim estuary, the main tributary of the Guanabara Bay. This system is located in a preserved area in the catchment basin of the bay, inside the Guapimirim Environmental Protection Area. The estuary presents a meandering channel with 3 meters mean depth. The aim of this work is to evaluate the salinity intrusion dynamics in response to the tide and freshwater discharge, as well as its effects on the water column structure and residence time. Surveys were performed to assess the salinity structure along the estuary main channel under different freshwater discharges (dry and rainy period) and tide (neap and spring). The results showed significant differences in the water column structure, presenting high stratification in neap tide and conditions homogeneous in spring tide. The salinity front (SF) showed a bigger displacement in the spring tide. Under highly stratified conditions, in neap tide, its displacement was bigger with smaller tidal amplitude. The location of SF inside of the estuary, in the high water, was influenced manly by freshwater discharge. The residence time in the Guapimirim estuary was longer in neap tide and dry period, presenting a good relationship with freshwater discharge.
\end{abstract}

Keywords: Guapimirim estuary, salinity intrusion, residence time.

RESUMO. Este trabalho foi desenvolvido no estuário de Guapimirim, principal tributário da Baía de Guanabara. Este sistema se localiza em uma área ainda preservada na bacia de drenagem da baía, dentro da Área de Proteção Ambiental de Guapimirim. 0 estuário apresenta um canal meandrante com uma profundidade média de 3 metros. 0 objetivo deste trabalho consiste em avaliar a dinâmica da intrusão salina em resposta a atuação dos processos físicos como a vazão fluvial e a maré, assim como, sua consequência na estrutura da coluna d'água e tempo de residência. Foram realizados levantamentos sobre a estrutura salina ao longo do canal principal do estuário em diferentes condições de vazão fluvial (período seco e chuvoso) e maré (quadratura e sizígia). Os resultados mostraram diferenças marcantes na estrutura da coluna d'água sendo estratificado em maré de quadratura e mais homogêneo em maré de sizígia. A frente salina apresentou um maior deslocamento em maré de sizígia. Em condições de alta estratificação, em maré de quadratura, o maior deslocamento da frente salina esteve associado a uma menor amplitude da maré. A vazão fluvial foi o principal processo físico que atuou no alcance máximo da frente salina. 0 tempo de residência de uma parcela de água dentro do estuário de Guapimirim foi maior em condição de maré de quadratura e em período seco, apresentando boa relação com a vazão fluvial.

Palavras-chave: estuário de Guapimirim, intrusão salina, tempo de residência.

\footnotetext{
1 Departamento de Geologia e Geofísica Marinha/LAGEMAR, Universidade Federal Fluminense, Av. General Milton da Costa s/n, Gragoatá, 24210-346 Niterói, RJ, Brazil. Phone/Fax: +55(21) 2629-5932 - E-mails: gustavoocn@yahoo.com.br; jabneto@id.uff.br; allansan@uol.com.br; michelvicente@oi.com.br; cguizan@id.uff.br 2 Universidade Federal do Rio de Janeiro, Instituto Alberto Luiz Coimbra de Pós Graduação e Pesquisa de Engenharia, Programa de Engenharia Oceânica. Centro de Tecnologia - Bloco c-203, Ilha do Fundão - P0 Box: 68508, 21945-970 Rio de Janeiro, RJ, Brazil - E-mail: susana@peno.coppe.ufrj.br

3 Universidade Federal do Rio de Janeiro, Instituto de Biofísica Carlos Chagas Filho, Programa de Biofísica Ambiental e Biotecnologia, Laboratório de Radioisótopos, IBCCF-CCS - UFRJ, Ilha do Fundão, 21941-900 Rio de Janeiro, RJ, Brazil - E-mail: ola@@biof.ufrj.br
} 


\section{INTRODUCTION}

One of the main characteristics of estuarine environments is the presence of a longitudinal salinity gradient that results from the mixing between sea and continental waters. The Iongitudinal salinity variation and the distance of the salinity intrusion is controlled by natural mechanisms, such as tidal range, river flow, geomorphological features of the estuary, sea level change, among others, as well as human activity interferences, like changes in the drainage basin, drainage channels, water intakes for urban water supply, land use and others (Prandle, 2009).

The knowledge of the salinity intrusion at estuaries is issues of great importance for society, thus encouraging studies aiming at environmental preservation and water resources management for various purposes.

The estuaries are located between the continent and the ocean and are, therefore, subjected to strong gradients of several environmental parameters. Under these circumstances, occur important physical, geological and biogeochemical processes, both peculiar and fundamental to maintaining this environment.

In general, the most intense gradients and the main physicobiogeochemical process are observed at the interface zone between two different bodies of water. Ionic strength and $\mathrm{pH}$ variation in this zone result in important changes in the behavior of some elements. Some of the dissolved elements, like chromium and iron, are incorporated into the suspended particulate matter, while others, like cadmium, are desorbed, moving from the particulate to the dissolved phase (Benjamin \& Leckie, 1981; Hatje et al., 2003).

A characteristic feature of this environment, found in many estuaries, is the Estuarine Turbidity Maximum (ETM) where the suspended sediments concentration is higher than either in the river or the adjacent coastal region. Several studies link the ETM formation and localization to the saline front, the interface between salt and fresh water (Uncles \& Stephens, 1993; Grabemann et al., 1997; Uncles et al., 1998a,b).

This interface presents higher sedimentation due to hydrodynamics and ionic strength changes that favor the formation of aggregates and flocs which increase settling velocity of particles (Eisma et al., 1980; Van Leussen, 1988; Eisma et al., 1991).

Estuaries are formed when sea and continental waters mix and any significant modification of the physical processes involved in this interaction can cause significant changes in salinity intrusion and important consequences for the environment. Estuaries on the northeastern Brazil have undergone environmental transformations due to water withdraw from the tributaries for economic purposes, such as aquaculture, irrigation, dams and others (Lacerda \& Marins, 2002). The Pacoti River estuary, I0cated in the Ceará State, is a good example of such modifications. The decreasing river flow allows greater influence of the marine physical processes, causing greater salinity intrusion and sediment transport into the estuary. As a result, mangroves currently occupy an area twice as large as in the 50's (Lacerda et al., 2007).

The Seine estuary natural features also underwent significant changes; about 150 years ago the estuary was shallow, meandering with broad tidal flats. The economic development of the area caused a large populational and industrial occupation, and thus irreversible changes such as dredging, landfills, construction of navigation channels, toxic substances dumping and others. Currently, there is only one deep channel connecting the river and the sea. These changes caused the salinity intrusion to migrate towards the sea, reduced estuary volume and average residence time, as well as increased sediment transport to coastal areas, creating mud banks on the continental shelf. The "geological role" of the estuary was, therefore, changed from a sink into a significant source of sediments to the coastal area (Avoine et al., 1981).

In some cases, the changes of the salinity intrusion extension bring socio-economic problems to the cities. The increasing salinity intrusion observed since 2003 in the estuary of the Pearl River (China), which is attributed to the varying sea level from global warming, affected the quality of drinking water in the cities of Macau and Zhuhai. The government had to pump water from an upstream location, thus increasing considerably the cost (Xinfeng \& Jiaquan, 2010).

Numerical models have been developed to assess and predict the extension of salinity intrusion either for economical or environmental preservation purposes (Wolanski \& Cassagne, 2000; Liu et al., 2001; Parsa \& Etemad-Shahidi, 2009).

The Guapimirim estuary is a major tributary of the Guanabara Bay. The environmental protection area established in the region, has preserved the environmental characteristics near the river mouth. Still, this estuarine system is subjected to changes that may occur in the drainage basin. Currently, land use consists of a few urban centers, intense agricultural activity, water withdraw to supply urban areas and fish farming activities (Amador, 1997). The recent installation of the Rio de Janeiro petrochemical complex (COMPERJ) may also have direct and indirect consequences to this estuarine system.

Thus, knowing the longitudinal distribution of salinity and its relation to river flow is important for planning and managing any kind of intervention in its drainage basin. This study aims at describing and understanding the salinity intrusion dynamics in response to river flow and tides, and its consequence on the estuary residence time. 


\section{STUDY AREA}

The Guapimirim River estuary is located northeast of the Guanabara Bay (Fig. 1), within the Guapimirim Environmental Protection Area (APA). This protected area was established on September 25, 1984 by Federal Decree 90225, to preserve the remaining mangroves in the interior of Guanabara Bay.

The Guapimirim estuary is the main tributary of the bay, contributing about $20.8 \%$ of the total volume of incoming freshwater (Kjerfve et al., 1997). The Macacu, Guapiaçu and Guapimirim rivers are the most important tributaries of this estuary. The catchment area extends over $1.640 \mathrm{~km}^{2}$, bounded to the north and northwest by Serra dos Órgãos, to the northeast by Serra de Macaé de Cima, to the east by Serras da Botija and Monte Azul and to the south by Serras do Sambê and dos Garcias (Negreiro et al., 2002).

This estuary present micro and mixing tide, with amplitude is about $40 \mathrm{~cm}$ in neap tide, while in spring tide it can reach approximately $150 \mathrm{~cm}$.

Currently, the land use of this drainage basin is occupied by few urban centers, pastures and farms. Water intakes from some rivers supply the towns of Cachoeira de Macacu, Guapimirim, São Gonçalo, Itaboraí and Niterói, as well as irrigation and fish farming activities. The most rugged and steep regions are still covered by remaining native vegetation. Its drainage underwent major changes during the period of occupation. In 1954, the former Departamento Nacional de Obras e Saneamento (DNOS) created the Canal de Imunana, diverting water to supply the Laranjal treatment plant, in São Gonçalo. This changed the course of Macacu River, connecting it to Guapimirim River, thus increasing the Guapimirim estuary's catchment area.

The region near the river mouth kept its original features when the Guapimirim Environmental Protection Area (APA) as established. The estuary crosses an extensive mangrove area with meandering morphology. The bathymetry of the estuary follows the meandering channels showing greater depth on the erosive side of the channel. The depth of the main channel of the estuary is about $3 \mathrm{~m}$, reaching up to $5 \mathrm{~m}$ in some places (Fig. 1). The deeper portions correspond to meanders, becoming shallow again when the channel widens, and the process of fine sediment deposition begins. The region downstream of the mouth consists of two mud banks separated by the main channel of the estuary.

\section{METHODOLOGY}

\section{Survey data}

Some surveys were performed to collect data regarding the Guapimirim estuary salinity structure under different river discharge and tide conditions (spring and neap). The surveys were planned so sampling was performed during both tides for the same river discharge/flow and, therefore, during two consecutive weeks.

The information were obtained in the main channel of the Guapimirim estuary using a fast boat when the tide coincided with maximum flood (high tide) and ebb (low tide). The 28 sampling stations were distributed along the estuary about $300 \mathrm{~m}$ apart from each other (Fig. 1). The distance traveled was $12.5 \mathrm{~km}$ between the IBAMA (Instituto Brasileiro do Meio Ambiente e dos Recursos Naturais Renováveis) head office and $1.5 \mathrm{~km}$ downstream from the river mouth, and lasted about $3 \mathrm{~h}$ for each tide.

Salinity and temperature vertical profiles were obtained for each sampling station using a Seabird CTD, model SBE19p/us. Salinity variations along the estuary were expressed as relative depth $(z=z i / H)$, the ratio between the measured depth $(z i)$ and local depth $(H)$ at the sampling time. This removes the depth differences found for the same station depending on the tide, river flow and possible vessel displacements due to drifting.

\section{Supplementary data Changing Sea Level}

The information on changing sea level was used to plan the data surveys and sample analysis, and corresponds to the harmonic constants obtained for tide stations: Ilha de Paquetá, from March 2008 until March 2009, and Ilha do Boqueirão, from March until July 2009. These data were provided by the National Oceanographic Database of the Diretoria de Hidrografia e Navegação (DHN)/Marinha do Brasil.

\section{River discharge}

River discharge information regarding the Gauging Station closest to the study area, the CEDAE (Companhia Estadual de Águas e Esgotos) dam, was provided by the Instituto Estadual do Ambiente (INEA). This station is located in Macacu River, upstream from the IBAMA head office, and represents the flow of virtually the entire drainage basin of the Guapimirim estuary.

The river discharge was calculated from the gauge height measurements and the rating curve for the gauging station of the CEDAE dam, described below.

$$
Q=95.153 \times(H-1.1)^{1.057}
$$

where $Q$ is the freshwater discharge $\left(\mathrm{m}^{3} \mathrm{~s}^{-1}\right)$ and $H$ is the gauge height ( $m)$.

\section{Residence Time}

Residence time $(R T)$ was estimated by the fraction of freshwater retained in the mixing zone $(M Z)$. The estuary was divided into 

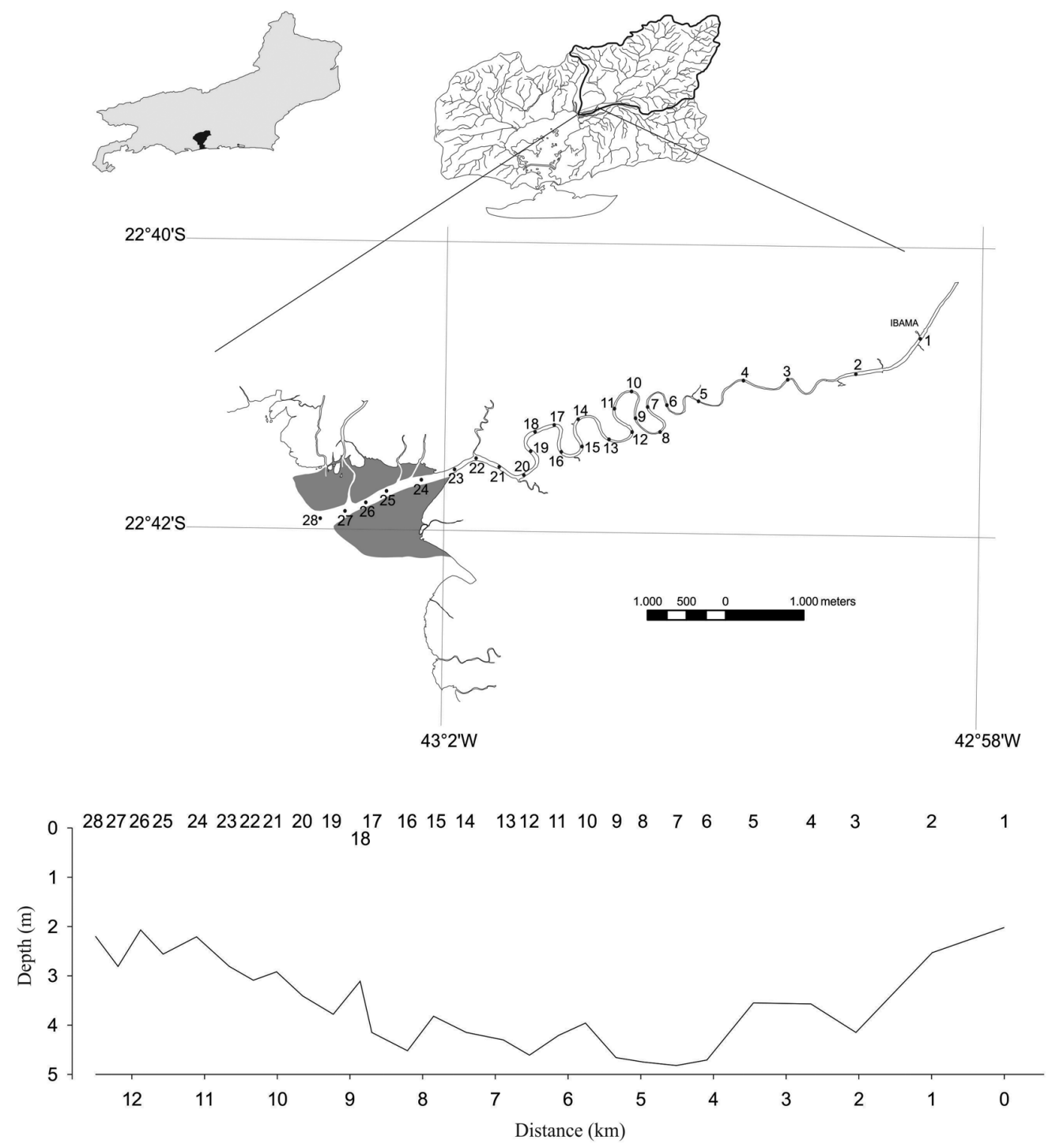

Figure 1 - Map of Guapimirim estuary inside the Guanabara Bay, Rio de Janeiro State, showing the sampling stations and the longitudinal bathymetric profile in the main channel.

several segments corresponding to the distance between sampling points. The last segment corresponded to station 25, downstream of the mouth from where other rivers, such as the Magé channel, might influence.

The $R T$ can then be expressed as the ratio:

$$
R T=\frac{\sum_{i=1}^{n}\left(f_{i} * V_{i}\right)}{Q_{f}}
$$

where $f_{i}$ is the freshwater fraction trapped in segment $i, V_{i}$ is the volume of segment $i$ and $Q_{f}$ is the freshwater discharge.

From the definition of salinity and the mass conservation principle in seawater, $f_{i}$ can be obtained from the average salinity of estuary and of the salinity in the adjacent coastal area, according to the expression:

$$
f_{i}=\frac{S_{o}-S_{i}}{S_{o}}
$$

The salinity of segment $\left(S_{i}\right)$ was given by the arithmetic mean of salinity at each end of the segment. The average salinity at each point is given by the average of the vertical profile weighed by the depth. The average salinity of the estuary as a whole was given by the average salinity weighed by volume.

This method assumes that the salinity in the coastal area $\left(S_{0}\right)$ does not vary significantly. As the study area is a estuary inside of the bay, the characteristics of the water downstream from the mouth reflect the changes that occur in the bay. Thus, the salinity at the mouth $\left(S_{0}\right)$ was assumed to be the highest value 


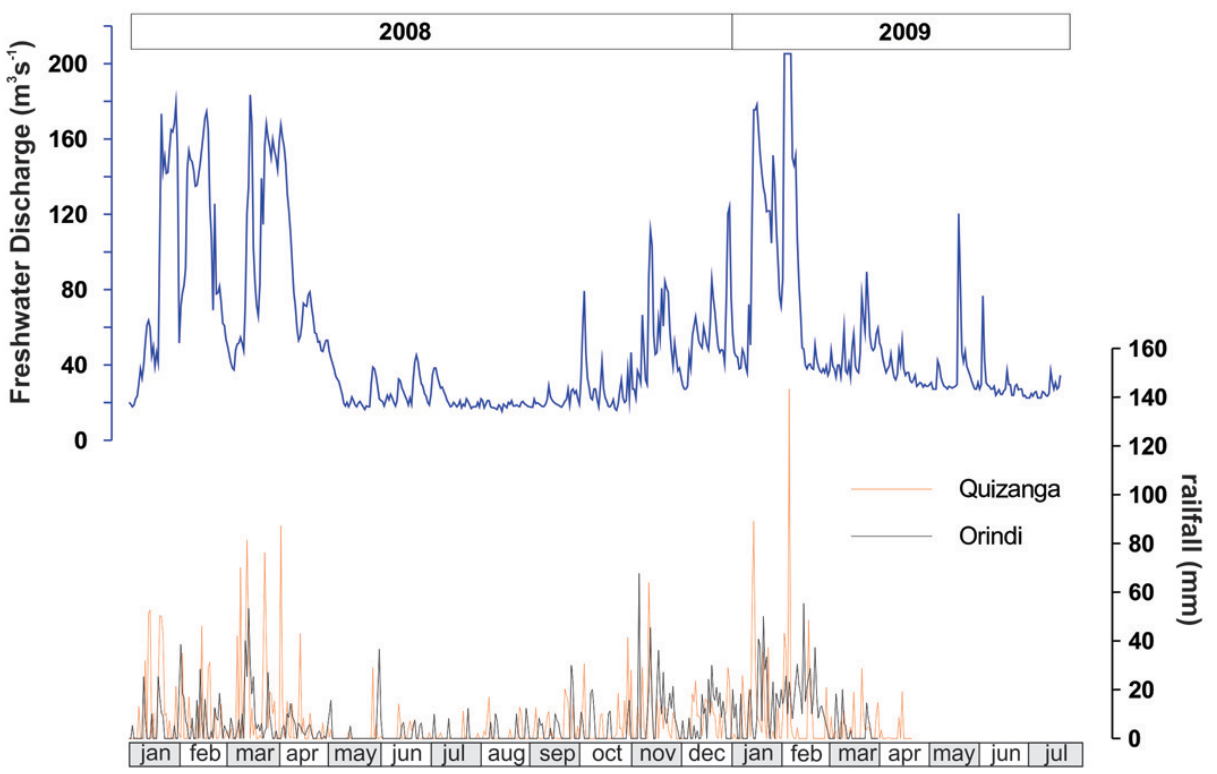

Figure 2 - Temporal Variation of the freswater discharge in the gauging station located in CEDAE dam and rainfall in the pluviometric stations of the Quizanga and Orindi.

during each survey, presenting significant variations throughout the year.

The freshwater discharge considered by this method can be a source of error in the $R T$ calculation (Sheldon \& Alber, 2002). This method assumes a fundamentally stationary condition, but the river freshwater discharge is rarely constant in the time scale of interest. Alber \& Sheldon (1999) showed that the most appropriate time scale for a more adequate flow rate is the residence time itself. As initially, we did not know the $R T$, the used freshwater discharge was the first measurement of the day. After determining a better $R T$ value, an average freshwater discharge was determined for the period, and a new $R T$ value was calculated using the new flow rate.

\section{RESULTS}

\section{Freshwater Discharge}

The freshwater discharge data at the CEDAE dam station, in 2008 and 2009, show that the Guapimirim estuary is subjected to considerable fluctuations at different times scales (Fig. 2). Two distinct periods are observed for flow rates during the year, which reflect rainfall seasonality. The year can be divided into two well defined periods: rainy summer season when the freshwater discharge increases up to about $205 \mathrm{~m}^{3} \mathrm{~s}^{-1}$; and dry winter season, when freshwater discharge can be as low as $18 \mathrm{~m}^{3} \mathrm{~s}^{-1}$.

During heavy rainfall, depending on its intensity, natural char- acteristics of the river basin, and land use, the runoff into the river increases the freshwater discharge almost simultaneously. The freshwater discharge and rainfall temporal variations of the drainage basin of the Guapimirim estuary demonstrate pulses of large flows after heavy rains, especially in the summer months when the records show the occurrence of heavy orographic rainfall (see Fig. 2). These events last for about 1 day, showing the short residence time of the water in the drainage basin, unlike large basins such as the Amazon River, for which Mortatti et al. (1994) estimated rain water residence time to be between 2 and 3 months.

In addition to the seasonal variation, interannual differences are also observed between these periods, such as more intense rainy season in a given year, as well as drier periods. In 2008, the frequency and intensity of rainfall during the summer months were higher than in 2009, and presented a more intense dry period.

\section{Longitudinal Salinity Structure}

Table 1 shows the tidal range and freshwater discharge during the sampling periods.

\section{Rainy Season - Spring Tide}

The freshwater discharge conditions in the surveys conducted in spring tide during the rainy season showed some differences 
(Table 1). The survey on March 24, 2008 shows the highest river flow rate $\left(152.5 \mathrm{~m}^{3} \mathrm{~s}^{-1}\right)$, which was significantly higher than other samplings and closer to the climatological maximum $\left(205 \mathrm{~m}^{3} \mathrm{~s}^{-1}\right)$. On the other hand, the tidal ranges were similar between surveys. During low tide, the surveys showed the same water column structure with the river water occupying the entire area of the estuary. On March 25, 2009, the saline front detected in the outer stations, downstream from the mouth, resulted from the sampling time, when the tide was beginning to flood and, therefore, the saline front was moving towards the estuary (Fig. 3).

Table 1 - Data on tide conditions (predicted range) and river flow rate, in the gauging station of the CEDAE dam, during the surveys conducted in the Guapimirim estuary.

\begin{tabular}{|c|c|c|c|c|}
\hline \multirow{3}{*}{ Season } & \multirow{2}{*}{ Date } & \multicolumn{2}{|c|}{ Tidal } & \multirow{2}{Q}{$Q$} \\
\cline { 3 - 4 } & & Type & Range(m) & $\left(\mathrm{m}^{3} \mathrm{~s}^{-1}\right)$ \\
\hline \multirow{6}{*}{ Wet } & $03 / 24 / 08$ & $\mathrm{Sp}$ & 1.15 & 152.5 \\
& $03 / 31 / 08$ & $\mathrm{~Np}$ & 0.46 & 156.5 \\
& $03 / 13 / 09$ & $\mathrm{Sp}$ & 1.23 & 38.4 \\
& $03 / 18 / 09$ & $\mathrm{~Np}$ & 0.35 & 45.8 \\
& $03 / 25 / 09$ & $\mathrm{Sp}$ & 1.48 & 51.7 \\
\hline \multirow{6}{*}{ Dry } & $07 / 17 / 08$ & $\mathrm{Sp}$ & 1.22 & 20.5 \\
& $09 / 22 / 08$ & $\mathrm{~Np}$ & 0.26 & 19.0 \\
& $09 / 30 / 08$ & $\mathrm{Sp}$ & 1.29 & 26.3 \\
& $06 / 08 / 09$ & $\mathrm{Sp}$ & 1.29 & 28.7 \\
& $06 / 30 / 09$ & $\mathrm{~Np}$ & 0.58 & 32.0 \\
& $07 / 08 / 09$ & $\mathrm{Sp}$ & 1.29 & 25.8 \\
\hline
\end{tabular}

The salinity structure was different between the surveys in the high water. On March 24, 2008, the water column was vertically homogeneous, without difference on the salinity between the surface and the bottom, thus showing complete mixing. The samplings of March 13, 2009, showed a small stratification with salinity values slightly lower up to $1 \mathrm{~m}$ deep. On March 25, 2009, the higher slopes of the isohalines highlight higher stratification. The difference of salinity between the surface and the bottom achieved about 10. The stratification observed at nearby station 23 on March 13, 2009, represents the salinity structure at a moment, before the high tide, when the tidal current strength was not strong enough to homogenize the water column.

\section{Rainy Season - Neap Tide}

The freshwater discharges were completely different in the two surveys conducted in neap tide during the rainy season (see Ta- ble 1). The freshwater discharge in March 2008 was much higher than in March 2009.

On March 31, 2008 the estuary was practically completely occupied by the river water both at low and high tide. Saline front was detected only at remote stations downstream from the mouth (Fig. 4). The stratification observed at the interface between the two water masses became more pronounced in high tide; the bottom water reached salinity higher than 11 and at the surface lower than 1. On March 18, 2009 the saline front was upstream of the mouth during the entire tidal cycle. The water column was highly stratified, more pronounced in low tide, and the saline front displayed the shape of a salt wedge.

\section{Dry Season - Spring Tide}

The freshwater discharge in spring tide during the dry period were similar, being slightly lower on July 17, 2008 and higher on June 8,2009 . The tidal range was about the same for all samplings.

On July 17, 2008, the water column was stratified in low tide. From station 21, the water near the bottom was more saline, leaving SF near the mouth of the estuary. At high tide, the water column was vertically homogeneous, indicating efficient mixing as the SF advanced towards to upper estuary.

On September 30, 2008 and July 8, 2009, in low tide, the estuary was filled with freshwater, while at high tide the SF presented a homogeneous water column (Fig. 5).

On June 8, 2009, in low tide, the SF was in the lower estuary, downstream of the mouth, with homogeneous water column. However, in high tide, the SF was stratified, probably due to higher freshwater discharge compared to other survey taken in the same tide over the dry period.

\section{Dry Season - Neap Tide}

The surveys conducted in spring tide during the dry period resulted in different freshwater discharge, with lowest and highest values found for September 22 and June 30, 2009, respectively.

Both surveys had the same general characteristics; the water column was stratified in low and high tide (Fig. 6). The survey on September 22, 2008 displayed lower stratification in low tide near the SF. In high tide, the more saline water advanced upstream into the estuary near the bottom, increasing stratification. On the other hand, the survey on June 30, 2009 did not show significant difference between high and low tide. Both had the same characteristics, with more stratification in low tide while the SF remained inside the estuary and the river water concentrated on the surface. 


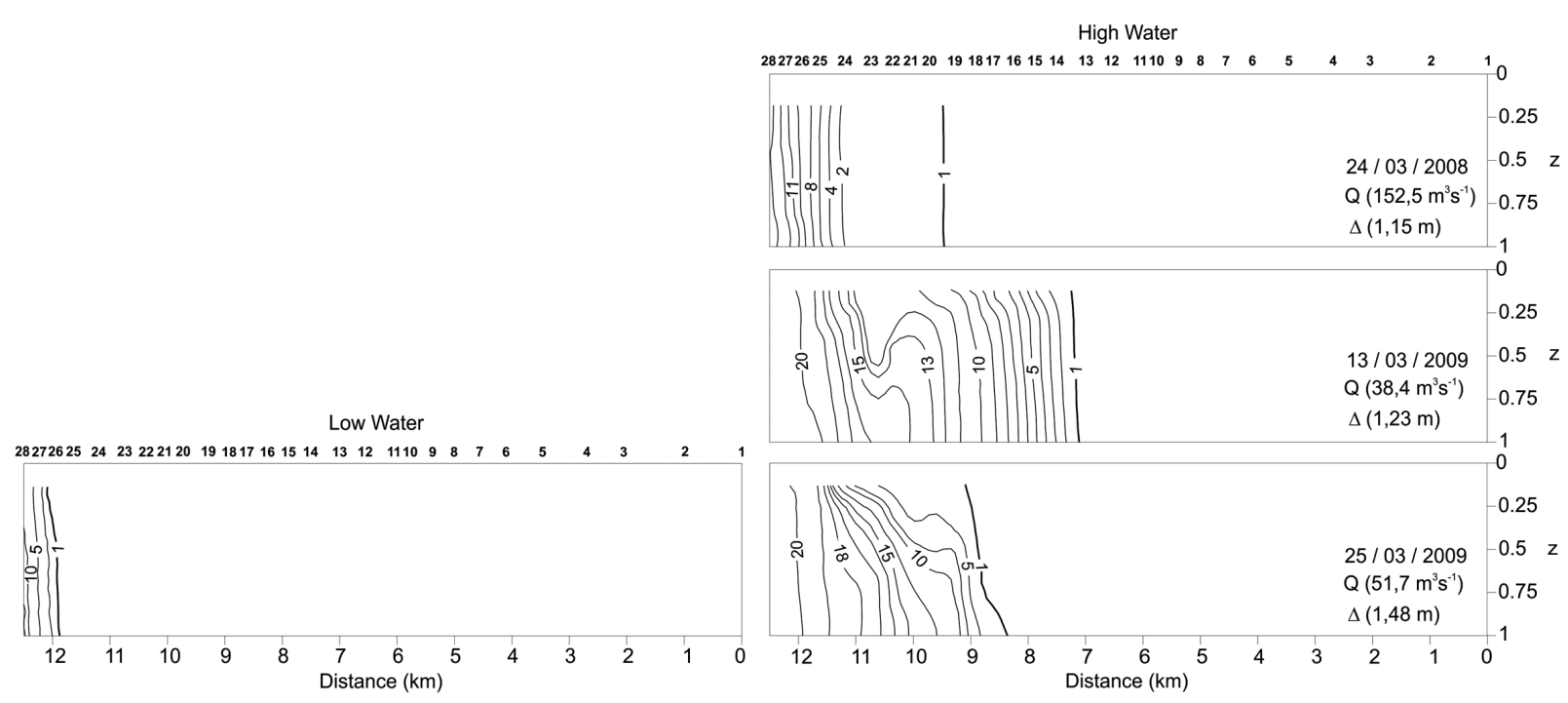

Figure 3 - Longitudinal variation of salinity in the Guapimirim estuary, during wet season in spring tide. $Q=$ freshwater discharge and $\Delta=$ tidal range during sampling.

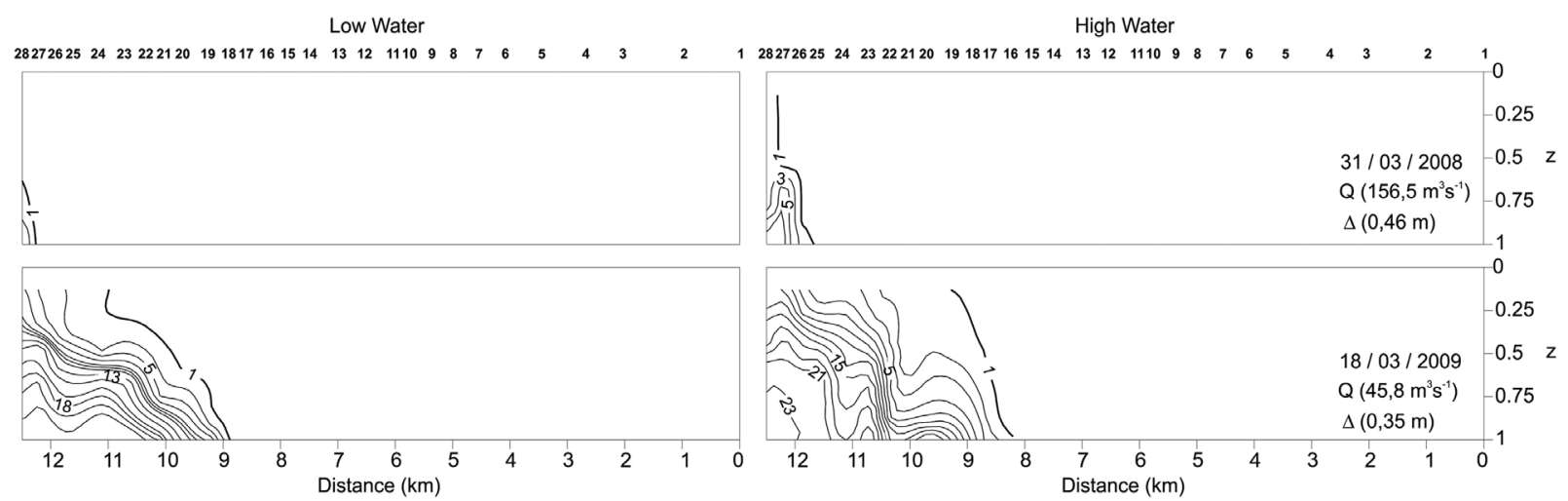

Figure 4 - Longitudinal variation of salinity in the Guapimirim estuary, during wet season in neap tide. $Q=$ freshwater discharge and $\Delta=$ tidal range during sampling.

\section{Salinity Front Movement (SF)}

The SF is the interface between the river and the adjacent coastal water, which consisted of the Guapimirim River and the Guanabara Bay water. This interface indicates the limit between the two water masses and is defined by an isohaline. In the literature, the SF is defined by a variety of isohaline values, such as 0.5 UPS (Capo et al., 2006), 1 UPS (Uncles \& Stephens, 1993), 5 UPS (Lerczak et al., 2009) or up to 6 UPS (Kurup et al., 1998).

There is no clearly defined criterium in the literature to establish the most appropriate salinity value that determines the interface between the water masses. Hunt et al. (2004) used the 5 UPS isohaline to determine the SF based on the argument that at this salinity the flocculation process occurs. However, Van Leussen (1998) discussed the influence of salinity on flocculation, noting that depending on the characteristics of the particle, this process can occur at salinities ranging from 1 to 7 UPS.

This study uses the 1 UPS isohaline, based on the results described so far, which shows a strong influence of continental water mass along the estuary. The SF position is given by the distance between sampling station 1 and the location where the isohaline 1 touches the bottom of the estuary.

At neap tide, both in the dry and rainy season, the saline front moved less between low and high tide, compared to spring tide. In March 2008, when the freshwater discharge was maximum $\left(156 \mathrm{~m}^{3} \mathrm{~s}^{-1}\right)$, the SF displacement was the lowest reaching a maximum near the last sampling point (28), downstream of the mouth of the estuary (Fig. 7). The freshwater discharge was so intense during this period that the tidal movement was contained 


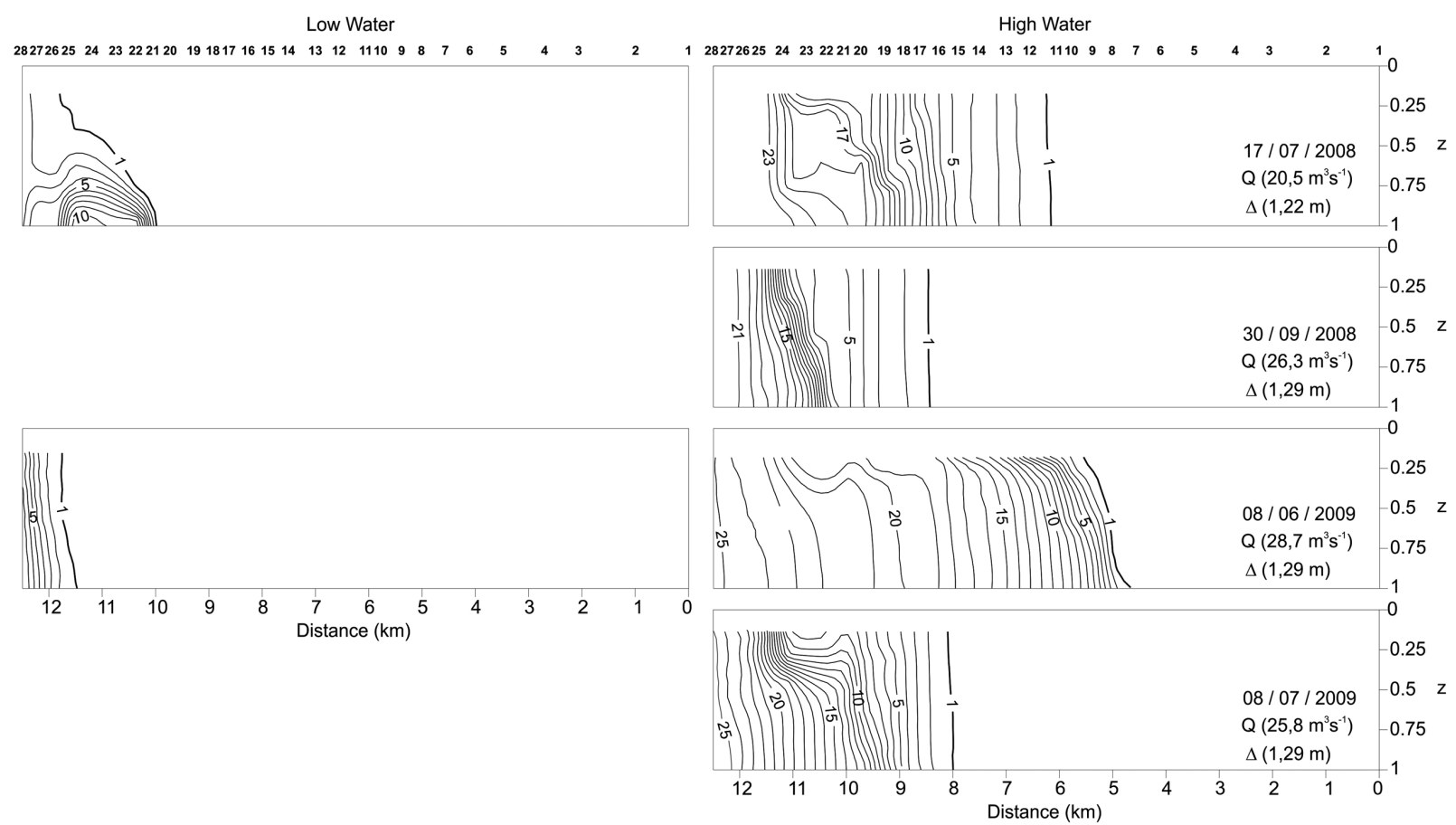

Figure $\mathbf{5}$ - Longitudinal variation of salinity in the Guapimirim estuary, during dry season in spring tide. $Q=$ freshwater discharge and $\Delta=$ tidal range during sampling.

Low Water

High Water

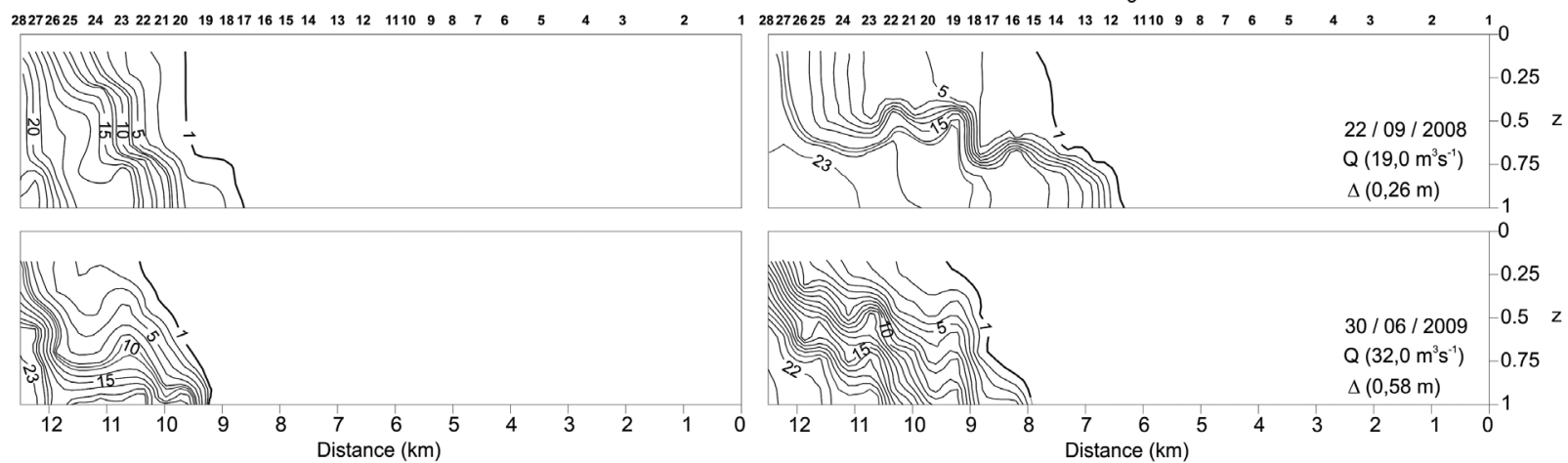

Figure 6 - Longitudinal variation of salinity in the Guapimirim estuary, during dry season in neap tide. $Q=$ freshwater discharge and $\Delta=$ tidal range during sampling.

beyond the morphological limits. In the other cases of neap tide, the SF displacement was a bit higher, especially in September 2008. In almost all neap tide surveys, the SF remained upstream of the mouth. With a lower freshwater discharge, the SF moved upstream into the estuary and remained there during the studied tidal cycle. The SF displacements in neap tide ranged from 0.6 to $2.5 \mathrm{~km}$.

In spring tide, the SF displacement was significantly higher. Except for July 17, 2008, in all surveys the minimum reach at low tide was downstream of the mouth. This result shows that in this tidal condition the properties of the estuary are subjected to bigger variations. In low tide, the estuary was almost completely filled with freshwater. However, in high tide, salinity increased as the SF advanced. The SF displacements in spring tide reached about 3-6 km (Fig. 7).

Regardless of tide, taking into account possible errors in determining the SF maximum reach, there was a relationship between the freshwater discharge increases and the location of the maximum intrusion of the SF. Comparing the surveys in September 2008 (neap and spring tide), was observed that the maxi- 
mum intrusion of SF reached in neap tide was higher than that of spring tide due to the smaller freshwater. The difference between the maximum intrusion of SF of the both tides was approximately $2 \mathrm{~km}$. Another example is given by the surveys in the spring tide of March 24, 2008 and June 8, 2009. The first occurred at maximum river flow rate $\left(152.5 \mathrm{~m}^{3} \mathrm{~s}^{-1}\right)$ and the second in the dry season $\left(28.7 \mathrm{~m}^{3} \mathrm{~s}^{-1}\right)$. The difference between the SF intrusions was almost $5 \mathrm{~km}$.

Distance $(\mathrm{km})$

$\begin{array}{llllllllllllll}13 & 12 & 11 & 10 & 9 & 8 & 7 & 6 & 5 & 4 & 3 & 2 & 1 & 0\end{array}$

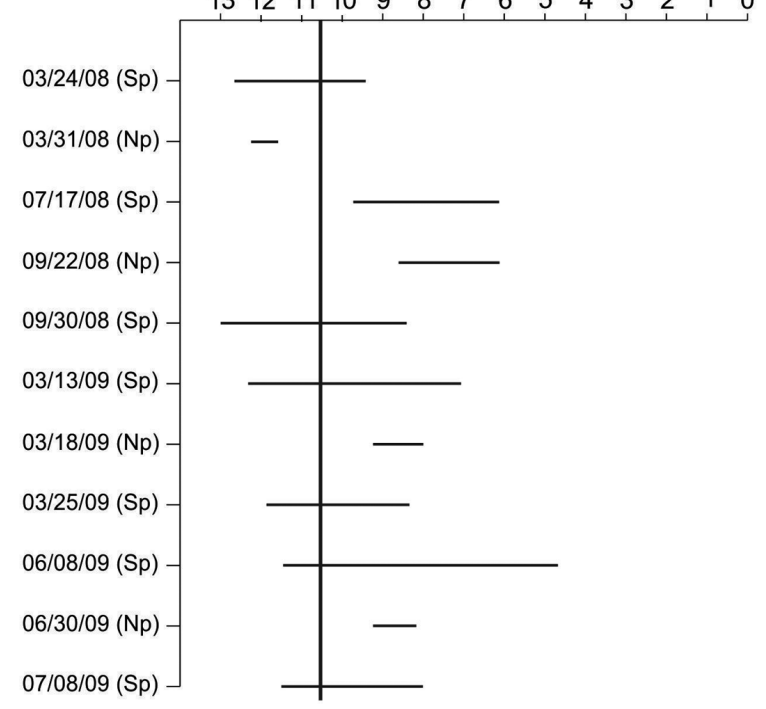

Figure 7 - Displacement of the salinity front (SF) between low and high water positions in all surveys. The black line corresponds to the mouth position.

\section{Residence Time (RT)}

The Table 2 shows the calculated $R T$ and the parameters used in the calculation. The results are significantly different for the rainy and dry seasons; the lower mean $R T$ during the rainy season was $4.23 \mathrm{~h}$ due to higher flow rate. The smaller SF displacement causes a portion of the water to remain longer in the estuary.

\section{DISCUSSION AND CONCLUSION}

The salinity variation along the estuary is a consequence of the interaction between physical processes that are involved in the mixing of the water. The intensity of this mixture varies according to the magnitude of each process at time scales that span from seconds to centuries (Dyer, 1997). The tide and river flow rate are the main physical processes that interact with the morphology to generate important mechanisms for longitudinal and vertical salt dispersion (Fisher, 1976). The wind is an important physical process for salt dispersion in estuarine systems where the large dimensions and the orientation favor its action (Goodrich et al., 1987).
This study did not investigate the role of either wind or wave height. It was assumed that these physical processes have little influence on the estuary dynamics compared to the tides and river flow rate. The winds and the resulting waves may somehow influence the two farthest stations downstream of the mouth when acting on the southwest quadrant. Still, their influence is small since the estuarine system is located in a sheltered region inside the Guanabara Bay and occupied mostly by mangrove vegetation on its banks and flood plains, preventing the action of winds from any direction.

The time series analysis of freshwater discharge showed that the Guapimirim estuary is subject to temporal variations ranging from days to years. These temporal variations of freshwater and the tidal condition are reflected in the structure of the water column. A clear difference was found in the water column structure in neap and spring tides, regardless the time of the year. The water column was highly stratified in neap tide and more homogeneous in spring tide. The influence of tide varied according to the tidal range (barotropic component). In neap tide, the mixing processes were less effective due to lower current speed, which, coupled with the baroclinic component, sustained the more saline water into the estuary during the tidal cycle, resulting in a SF shaped as a salt wedge. In spring tide, the tidal current had a greater influence. The turbulence generated close to the bottom and spread throughout the water column resulted in more intense mixing. Similar results were reported for the estuaries of Columbia/USA (Jay \& Smith, 1990) and Tamar/UK (Uncles \& Stephens, 1993).

Some important variation intertidal regarding the structure of the water column can be observed. The stratification in neap tide was different between low and high tide in almost all samples. This comparison was performed using the stratification parameter $(\delta S /<S>$ ) defined by Hansen \& Rattray (1966), which relates the difference in salinity between the bottom and the surface $(\delta S)$ with the average salinity of the water column $(<S>)$. This parameter was calculated for the location where isohaline 1 meets the free surface. In high water, the water column was more stratified than in low water in almost all surveys, except on June 30, 2009. In this tidal condition, the saline water moves towards to upper estuary near the bottom, increasing the salinity difference between the surface and the bottom. The advance of more saline water is driven by both the barotropic and baroclinic components of the tide, which during the flood tide act in the same direction. Stratification decreased during low tide due to lower salinity near the bottom, caused by the retreat of saline water and the mixing of the two water masses (Fig. 8). 
Table 2 - The residence times and the values of the parameters used in the calculation, Guapimirim estuary.

\begin{tabular}{|c|c|c|c|c|c|c|}
\hline Season & Date & Tidal & $Q_{f}\left(\mathrm{~m}^{3} \mathrm{~s}^{-1}\right)$ & $S_{0}$ & $\bar{S}$ & $R T(\mathrm{hr})$ \\
\hline \multirow{6}{*}{ Wet } & $03 / 24 / 08$ & $\mathrm{Sp}$ & 152.5 & 19.8 & 0.25 & 1.67 \\
& $03 / 31 / 08$ & $\mathrm{~Np}$ & 156.5 & 14 & 0.02 & 1.90 \\
& $03 / 13 / 09$ & $\mathrm{Sp}$ & 38.3 & 21.7 & 2.80 & 6.78 \\
& $03 / 18 / 09$ & $\mathrm{~Np}$ & 45.8 & 23.35 & 2.57 & 5.80 \\
& $03 / 25 / 09$ & $\mathrm{Sp}$ & 51.7 & 21.6 & 2.06 & 5.02 \\
\cline { 2 - 6 } & & & & & Mean & 4.23 \\
\hline \multirow{6}{*}{ Dry } & $07 / 17 / 08$ & $\mathrm{Sp}$ & 20.5 & 25.5 & 1.20 & 12.52 \\
& $09 / 22 / 08$ & $\mathrm{~Np}$ & 19.4 & 25 & 4.32 & 13 \\
& $09 / 30 / 08$ & $\mathrm{Sp}$ & 24.5 & 22.6 & 1.62 & 10.49 \\
& $06 / 08 / 09$ & $\mathrm{Sp}$ & 28.7 & 25.4 & 5.45 & 8.09 \\
& $06 / 30 / 09$ & $\mathrm{~Np}$ & 32.0 & 23.8 & 2.22 & 8.40 \\
& $07 / 08 / 09$ & $\mathrm{Sp}$ & 25.8 & 26 & 2.33 & 10.54 \\
\cline { 5 - 6 } & & & & & Mean & 10.51 \\
\hline
\end{tabular}

In situations of high stratification, as found in neap tide, the main mechanisms of generation of turbulence and mixing are located at the interface between the two bodies of water (Geyer \& Farmer, 1989; Strang \& Fernando, 2001), since the turbulence generated at the bottom is very small due to the low speed of the tidal current. The water column structure during the sampling shows that the turbulence generated at the interface between surface and bottom layer was not strong enough to homogenize the water column, but only to decrease stratification in ebb tide.

On March 31, 2008, when the freshwater discharge was close to the climatological maximum $\left(156 \mathrm{~m}^{3} \mathrm{~s}^{-1}\right)$, stratification showed the same behavior, higher in high tide, though with smaller difference.

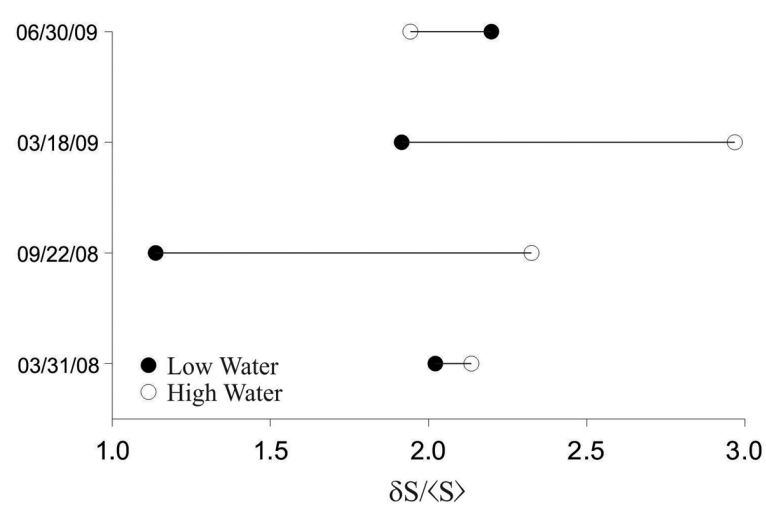

Figure 8 - Difference of the stratification between low and high water at neap tide.

Unlike other neap tide samplings, on June 30, 2009 stratification in low tide was slightly higher than in high tide (Fig. 8).
The tidal range was higher $(0.58 \mathrm{~m})$ indicating greater influence of the tidal barotropic component on the mixing of the water column in high tide. Still, the water column was stratified in ebb and flood tides.

In spring tide almost all surveys showed the same pattern in low tide. The river flow and the tidal barotropic component of the estuary acted to move the SF downstream of the mouth, leaving virtually the entire estuary occupied by river water. In high tide, the SF entering the estuary caused stratification differences as a function of freshwater discharge. The influence of the river flow in the water column structure is shown by the relationship between SF stratification in high water and freshwater discharge (Fig. 9). Stratification increased as freshwater discharge increased, indicating a greater influence of this process on the surface layer, generating a gentle vertical gradient in the SF. On June 8, 2009 the highest river flow also resulted in the highest SF stratification. When the freshwater discharge is close to the climatological maximum, as in the case of samples collected on March 24, $2008\left(152 \mathrm{~m}^{3} \mathrm{~s}^{-1}\right)$, the intensity of the current generated by this process was strong enough for the turbulence on the bottom to mixing the water column.

Jay \& Smith (1988) proposed a classification system that considered the baroclinic and barotropic tide parameters. The first, the internal Froude number ( $F b$, Eq. 4 ) is a estimative of water column stability and is defined by the relationship between the ratios of the surface $(d)$ and bottom $(D)$ layer thickness and between the horizontal $\left(\Delta \rho_{h}\right)$ and vertical $\left(\Delta \rho_{v}\right)$ density difference measured in the middle of the estuary. The second, the 


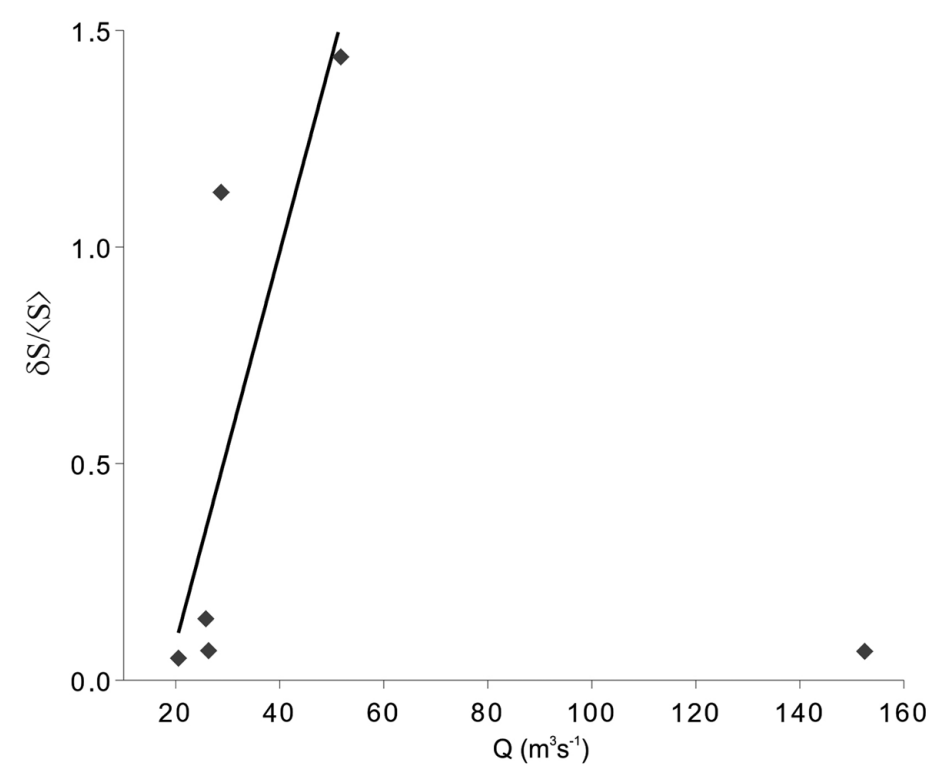

Figure 9 - Relationship between Stratification parameter and Freshwater Discharge in spring tide.

barotropic Froude number ( $F t$, Eq. 5) is given by the ratio between tide range $(\zeta)$ at the mouth of the estuary and its average depth $(H)$.

$$
\begin{gathered}
F b=\frac{d}{D}\left(\frac{\Delta \rho_{h}}{\Delta \rho_{v}}\right)^{\frac{1}{2}} \\
F t=\frac{\zeta}{H}
\end{gathered}
$$

The Jay \& Smith diagram (1988) shows the stratification only for high water situation since at low water this difference was very small in neap tide and in the spring tide the estuary was fully occupied by river water. The points distribution in the diagram confirms the observations regarding the water column structure (Fig. 10). The surveys in neap tide were classified as stratified and in spring tide virtually all were classified as weakly stratified. Therefore, the mixing mechanisms are more efficient in spring tide. Two surveys in spring tide (03/25/2009 and 06/08/2009) are located in the region classified as stratified according to the SF stratification, even though the saline structure is different from neap tide, due to increased river flow activity in high water.

The freshwater discharge difference between dry and wet seasons in the estuary of Guapimirim is evident; likewise the tidal range also presents significant differences between spring and neap tides. In spring tide, the tidal range can reach $1.5 \mathrm{~m}$ while in neap tide just over $0.5 \mathrm{~m}$. These differences in flow and tidal range act not only in the water column structure, but also in SF intrusion and its consequences within the estuary.
In spring tide, there was a larger displacement of the SF in the Guapimirim estuary. In low water, the SF was completely driven out of the estuary by the action of the river flow and the barotropic tidal component, and in high water moved towards to upper the estuary. Large tidal ranges in the mouth of the estuary are associated with more intense currents speed, resulting in bigger mixing of the water column and, consequently, lower stratification. In this case, the tidal range tends to increase the SF movement (Abraham et al., 1986). The tidal range in spring tide remained almost constant and, therefore, it was not possible to correlate with the SF displacement. Still, its displacement was much higher when compared to neap tide.

In highly stratified estuaries, the SF is driven upstream primarily by the baroclinic tidal component as a result of the horizontal density gradient. In the estuary of Columbia/USA, in periods of low river flow, Jay \& Smith (1990) found that the salinity intrusion was higher in neap than spring tide due to the higher baroclinic advection. In estuaries with high stratification, SF intrusion will be lower with increase of the mixing in the water column (Abraham et al., 1986). Unlike the surveys in spring tide, in the neap tide the range difference varied from 0.2 to $0.58 \mathrm{~m}$, and thus it was possible to assess its relationship with displacement and stratification. This relationship shows smaller displacement as the mixing increased caused by increasing range, thus reducing the influence of the baroclinic tidal component (Fig. 11).

In the Guapimirim estuary, during either wet or dry season in neap tide, the SF remained inside the estuary during the tidal cycle showing that the baroclinic tidal component influenced 


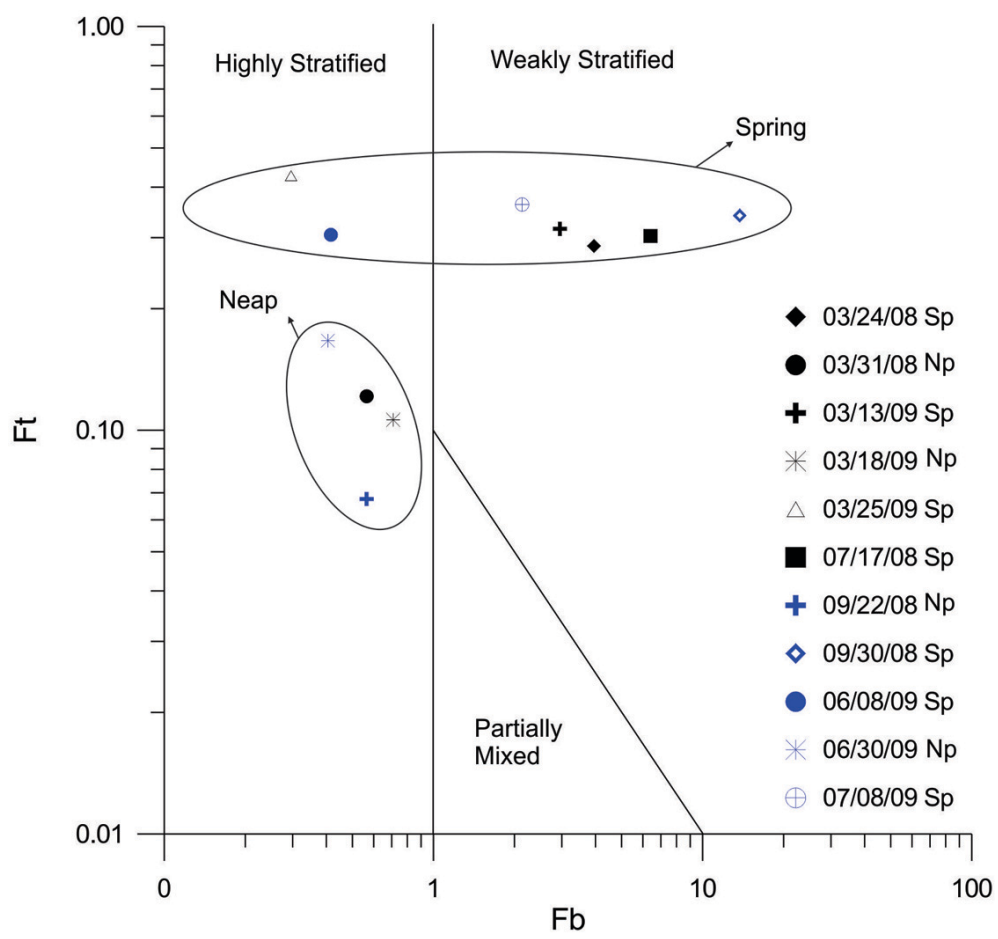

Figure 10 - Classification diagram proposed by Jay \& Smith (1988) taking into account the barotropic $(F t)$ and internal $(F b)$ Froude numbers.

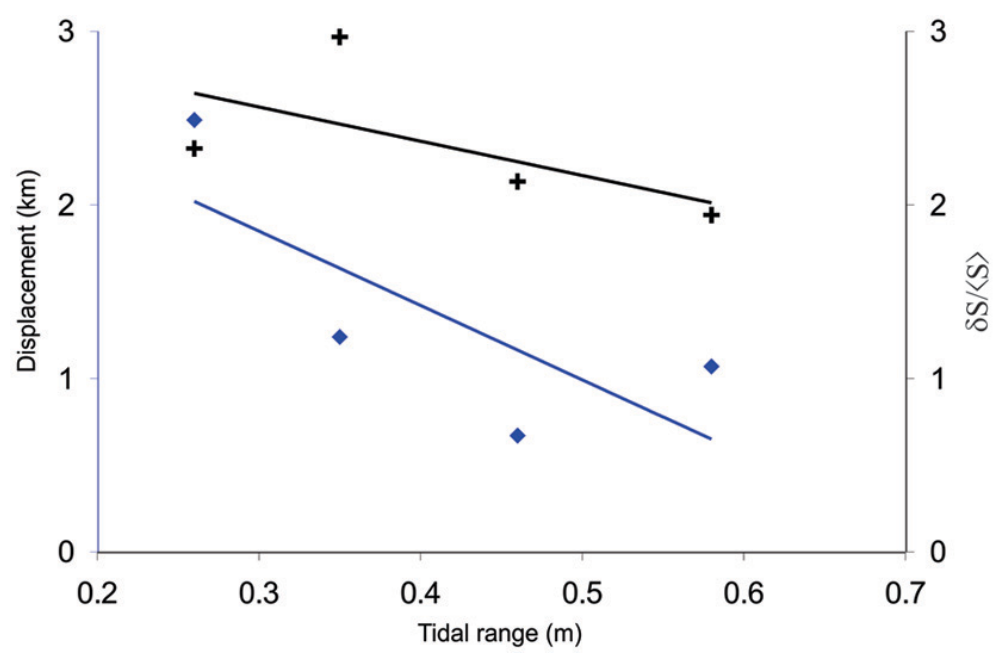

Figure 11 - Relationship between the displacement of the saline front (difference at low and high water), in blue, and the stratification parameter, in black, and with the tidal range in neap tide.

significantly its dynamics. However, on March 31, 2008 the SF was downstream from the mouth due to the intense freshwater discharge.

It is evident that the SF intrusion is controlled by the tidal range and the water column structure, especially in neap tide.
On the other hand, the maximum of the SF intrusion in high tide depends primarily on the freshwater discharge. Previous studies clearly demonstrate the influence and control of river flow $\left(Q_{f}\right)$ on the SF response threshold inside estuaries $(D)$ (Uncles \& Stephens, 1993; Kurup et al., 1998; Capo et al., 2006). This re- 


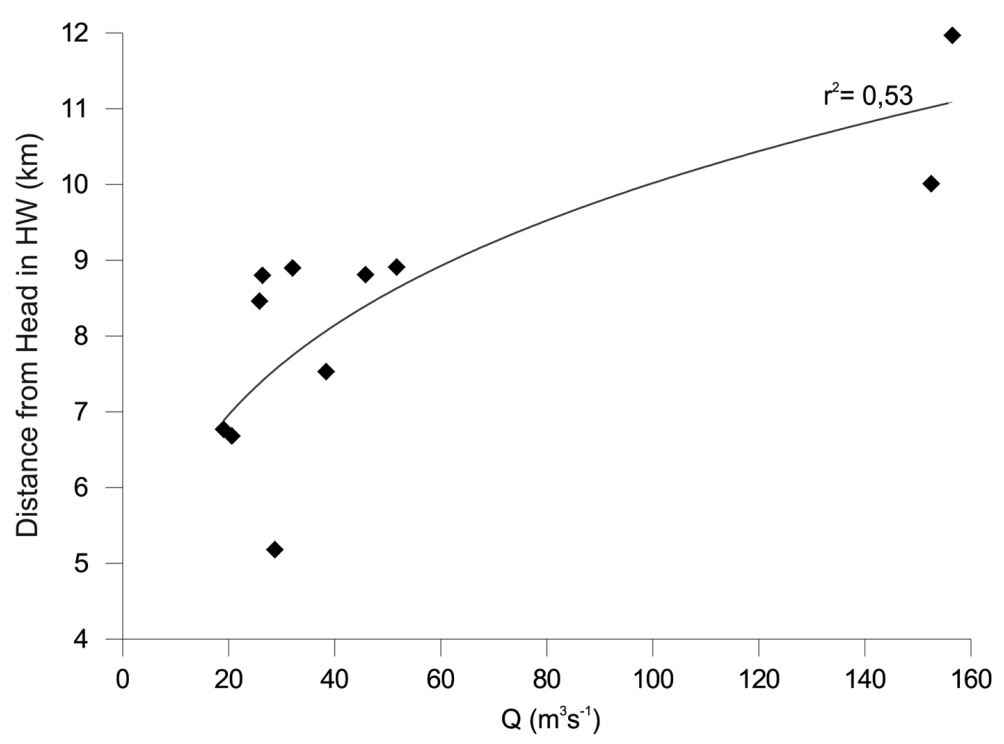

Figure 12 - Relationship between freshwater discharge $(Q)$ and the SF intrusion in high water.

lationship can be approximated by a potential regression. A good relationship was observed between the SF intrusion in each survey with freshwater discharge $\left(r^{2}=0.53\right)$ (Fig. 12), taking into account the errors when determining the SF maximum range. The resulting regression equation is described below.

$$
D=3.54 Q_{f}^{0.23}
$$

This relationship can be considered as a first approximation to estimate the Maximum SF intrusion as a function of freshwater discharge.

The interaction between the physical processes involved in mixing of the water masses determine the water column structure and the SF dynamics, such as the residence time of a portion of water inside the estuary according to Sheldon \& Alber (2002).

The results showed a strong relationship between river flow and residence time, being shorter in wet season and longer in the dry season, ranging from about 2-13 hours, respectively. $R T$ varied exponentially with the river flow (Fig. 13), as found in several previous studies (Pilson, 1985; McPhersons \& Miller, 1991; Sheldon \& Alber, 2002; Wang et al., 2004). This relationship shows that the higher the river discharge the lower the $R T$ in the estuary. The high $\left(r^{2}=0.99\right)$ correlation between these two variables shows that river flow is very important for determination of the $R T$ in Guapimirim estuary.

The Guapimirim estuary has a much shorter $R T$ compared with others around the world. Regardless of the season, the residence time in this study is measured in hours while in other estuaries $R T$ is measured in days (Table 3). Such differences may be related to the characteristics of each estuary. In general, the average and maximum salinity of such estuaries are far higher than that of the Guapimirim estuary. Furthermore, they have smaller differences between these values, i.e., the saline water remains longer inside these environments. Miranda et al. (2004) calculated the $R T$ in the Curimataú estuary, Rio Grande do Norte State, using the same methodology as in this study. The authors reported that $R T$ was shorter in spring tide due to a higher river flow. As in the present study, this result shows that the freshwater discharge has a great influence on the $R T$.

The results show that the Guapimirim estuary is an extremely dynamic environment, undergoing changes when any of the physical processes involved also change. Currently, the catchment area of the estuary is under major changes, especially due to the Petrochemical complex being built on the banks of its major tributaries and the growth of surrounding urban areas. This work was the first study conducted to understand the dynamics of the Guapimirim estuary. Thus, it is very important for the planning of future developments that might alter the performance of the main physical processes that determine its natural characteristics.

\section{ACKNOWLEDGMENTS}

The authors are grateful to CAPES and CNPq for the financial support to develop this project, to Instituto Brasileiro do Meio Ambiente e dos Recursos Naturais Renováveis (IBAMA) and head office of Guapimirim for the logistic support and the permission to perform the research inside the Guapimirim Environmental Protection Area. 


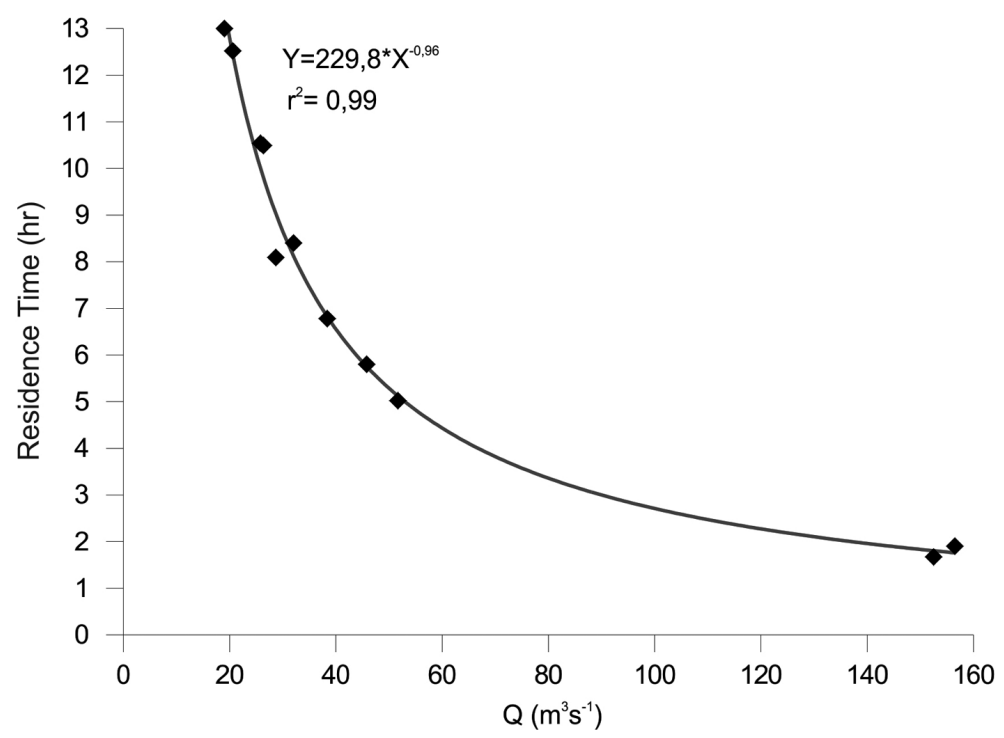

Figure 13 - Relationship between residence time and freshwater discharge $(Q)$.

Table 3 - Residence Time values obtained in estuaries worldwide.

\begin{tabular}{|c|c|c|c|}
\hline Estuary & Site & $R T$ (days) & References \\
\hline Guapimirim River & Rio de Janeiro, Brazil & $0.17-0.43$ & This work \\
Narragansett Bay & Rhode Island Sound, USA & $12.2-38.2$ & Pilson (1985) \\
Altamaha River & Georgia, USA & $2.3-5.9$ & Sheldon \& Alber (2002) \\
Bertioga Channel & São Paulo, Brazil & $2.5-3.2$ & Miranda \& Castro (1993) \\
Hudson River & New York, USA & $6-10.6$ & Ketchum (1951) \\
Curimataú River & Rio Grande do Norte, Brazil & $0.4-1.4$ & Miranda et al. (2004) \\
\hline
\end{tabular}

\section{REFERENCES}

ABRAHAM G, DE JONG P \& VAN KRUININGEN FE. 1986. Large-scale mixing process in a partly mixed estuary. In: BOWMAN MJ, BARBER RT \& MOOERS CNK (Eds.). Physics of shallow estuaries and bays. Springer-Verlag, N.Y, 6-21.

AMADOR E. 1997. Baía de Guanabara e Ecossistemas Periféricos: Homem e Natureza. Rio de Janeiro, ReproArte Gráfica e Editora, 539 pp.

ALBER M \& SHELDONJE. 1999. Use of a date-specific method to examine variability in the flushing time of Georgia estuaries. Estuarine, Coastal and Shelf Science, 49: 469-482.

AVOINE J, ALLEN GP, NICHOLS M, SALOMON JC \& LARSONNEUR C. 1981. Suspended - sediment transport in the Seine estuary, France: Effect of man-made modifications on Estuary shelf sedimentology. Marine Geology, 40: 119-137.

BENJAMIN MM \& LECKIE J0. 1981. Multiple-site adsorption of Cd, $\mathrm{Zn}$ and $\mathrm{Pb}$ on amorphous iron oxyhydroxides. Journal Colloid Interface Science, 79: 209-221.
CAPO S, SOTTOLICHIO A, BRENON I, CASTAING P \& FERRY L. 2006. Morphology, hydrography, and sediment dynamics in a mangrove estuary: The Konkoure Estuary, Guinea. Marine Geology, 230: 199-215.

DYER KR. 1997. Estuaries: A physical Introduction. 2ed., John Wiley \& Sons, N.Y., 195 pp.

EISMA D, BERNARD P, CADÉE GC, ITTEKKOT V, KALF J, LAANE R, MARTIN JM, MOOK WG, VAN PUT A \& SCHUMMACHER T. 1991. Suspended-matter particle size in some west-european estuaries; Part II: A review on floc formation and break-up. Netherlands Journal of Sea Research, 28(3): 215-220.

EISMA D, KALF J \& VEENHUIS M. 1980. The formations of small particles and aggregates in the Rhine Estuary. Netherlands Journal of Sea Research, 14(2): 172-191.

FISHER HB. 1976. Mixing and dispersion in estuaries. Annual Rev. Fluid Mechanics, 8: 107-133.

GEYER WR \& FARMER DM. 1989. Tide - Induced variation of the dynamics of a salt wedge estary. Journal of Physical Oceanography, 19: 1060-1072. 
GOODRICH DM, BOICOURT WC, HAMILTON P \& PRITCHARD DW. 1987. Wind - Induced destratification in Chesapeake Bay. Journal of Physical Oceanography, 17: 2232-2240.

GRABEMANN I, UNCLES RJ, KRAUSE G \& STEPHENS JA. 1997. Behaviour of Turbidity Maxima in the Tamar (U.K.) and Weser (F.R.G.) Estuaries. Estuarine, Coastal and Shelf Science, 45: 235-246.

HATJE V, PAYNE TE, HILL DM, McORIST G, BIRCH GF \& SZYMCZAK R. 2003. Kinetics of trace element uptake and release by particles in estuarine waters: effects of $\mathrm{pH}$, salinity, and particle loading. Environment International, 29(5): 619-629.

HANSEN DV \& RATTRAY M. 1966. New Dimensions in estuary classification. Limnology and Oceanography, 11(3): 319-325.

HUNT S, LEMCKERT CJ \& SCHACHT C. 2004. Location of turbidity maxima within a microtidal estuary and some limitations of laser in situ particle sizing. Journal of Coastal Research, 39: 520-525.

JAY DA \& SMITH JD. 1988. Residual circulation in and classification of shallow, stratified estuaries. In: DRONKERSJ \& VAN LEUSSENW (Eds.). Physical Process in Estuaries. Springer-Verlag, Berlin, 21-41.

JAY DA \& SMITH JD. 1990. Circulation, density distribution and neap spring transitions in the Columbia River Estuary. Progress in Oceanography, 25(1-4): 81-112.

KJERFVE B, DIAS GTM, FILIPPO AM \& QUARESMA VS. 1997. Oceanographic characteristics of an impacted coastal bay: Baía de Guanabara, Rio de Janeiro, Brazil. Continental Shelf Research, 17(13): 1609-1643.

KURUP GR, HAMILTPN DP \& PATTERSON JC. 1998. Modelling the effect of Seasonal flow variation on the position of salt wedge in a microtidal estuary. Estuarine, Coastal and Shelf Science, 47: 191-208.

LACERDA LD \& MARINS RV. 2002. River damming and changes in mangrove distribution. ISME/Glomis Electronic Journal, 2(1): 1-4.

LACERDA LD, MENEZES MOT \& MOLISANI MM. 2007. Changes in mangrove extension at the Pacoti River estuary, CE, NE Brazil due to regional environmental changes between 1958 and 2004. Biota Neotropica, 7(3): 67-72.

LERCZAKJA, GEYER WR \& RALSTONDK. 2009. The temporal response of the Length of a Partially Stratified Estuary to Changes in River Flow and Tidal Amplitude. Journal of Physical Oceanography, 17: 2232-2240; 39: 915-933.

LIU WC, HSU MH, KUO AY \& KUO JT. 2001. The influence of river discharge on salinity intrusion in the Tanshui Estuary, Taiwan. Journal of Coastal Research, 17(3): 544-552.

MILLER RL \& McPHERSONS BF. 1991. Estimating estuarine flushing and residence times in Charlotte Harbor, Florida, via salt balance and box model. Limnology and Oceanography, 36(3): 602-612.
MORTATTI J, PROBST JL \& TARDY Y. 1994. Avaliação do escoamento superficial da Bacia Amazônica através do transporte de material fluvial. Geochimica Brasiliense, 8(2): 235-243.

NEGREIROS DH, ARAUJO FP \& COREIXAS MA. 2002. Nossos Rios. Instituto Baía de Guanabara. 31 pp.

PARSA J \& ETEMAD-SHAHIDI A. 2009. Prediction of the influence of estuarine modifications on the salinity intrusion. Journal of Coastal Research, 56: 1390-1394.

PILSON MEQ. 1985. On the residence time of water in Narragansett Bay. Estuaries, 8(1): 2-14.

PRANDLE D. 2009. Estuaries: Dynamics, Mixing, sedimentation and Morphology. Cambridge University Press, N.Y., 236 pp.

SHELDON JE \& ALBER M. 2002. A comparison of residence time calculations using simple compartment models of the Altamaha River Estuary, Georgia. Estuaries, 25(6b): 1304-1317.

STRANG EJ \& FERNANDO HJS. 2001. Entrainment and mixing in stratified shear flows. Journal of Fluid Mechanics, 428: 349-386.

UNCLES RJ, EASTON AE, GRIFFITHS ML, HARRIS C, HOWLAND RJM, KING RS, MORRIS AW \& PLUMMER DH. 1998a. Seasonality of the Turbidity Maximum in the Humber - Ouse Estuary, UK. Marine Pollution Bulletin, 37(3-7): 206-215.

UNCLES RJ, HOWLAND RJM, EASTON AE, GRIFFITHS ML, HARRIS C, KING RS, MORRIS AW, PLUMMER DH \& WOODWARD MS. 1998b. Seasonal Variability of Dissolved Nutrients in the Humber - Ouse Estuary, Marine Pollution Bulletin, 37(3-7): 234-246.

UNCLES RJ \& STEPHENS JA. 1993. The freshwater - saltwater interface and its relationship to the turbidity maximum in the Tamar Estuary, UK. Estuaries, 16(1): 126-141.

VAN LEUSSEN W. 1988. Aggregation of particles, settling velocity of mud flocs: A review. In: DRONKERS J \& VAN LEUSSEN W (Eds.). Physical Processes in Estuaries. p. 347-404.

WANG C, HSU M \& KUO A. 2004. Residence time of the Danshuei estuary, Taiwan. Estuarine, Coastal and Shelf Science, 60: 381-393.

WOLANSKI E \& CASSAGNE B. 2000. Salinity intrusion and rice farming in the mangrove-fringed Konkoure River delta, Guinea. Wetlands Ecology and Management, 8: 29-36.

XINFENG Z \& JIAQUAN D. 2010. Affecting Factors of Salinity Intrusion in Pearl River Estuary and Sustainable Utilization of Water Resources in Pearl River Delta. In: FUKUSHI K, HASSAN KM, HONDA R \& SUMI A (Eds.). Sustainability in Food and Water: An Asian Perspective. p. 1117. 


\section{NOTES ABOUT THE AUTHORS}

Gustavo Vaz de Melo. Graduated in Oceanography from the Universidade do Estado do Rio de Janeiro, Master's and Doctorate in Marine Geology and Geophysics at the Universidade Federal Fluminense. Post Doctorate in Marine Geology, working in estuarine hydrodynamics and cohesive sediment dynamics, as well as in the sedimentary evolution of Guanabara Bay.

José Antonio Baptista Neto. Graduated in Geography at Universidade Federal Fluminense, in 1989. M.Sc. in Marine Geology and Geophysics obtained in 1993 at Universidade Federal Fluminense, and PhD in Geosciences obtained at the Queen's University, Belfast - Northern Ireland/UK in 1996. Professor at the Geology Department of Universidade Federal Fluminense, and coordinator of the Graduate Program in Dynamic of Ocean and Land (DOT).

Susana Beatriz Vinzón. Graduated in Water Resources Engineering from the Universidad Nacional del Litoral, Master's and Doctorate in Ocean Engineering at the Universidade Federal do Rio de Janeiro respectively. Currently, Adjunct Professor at the Universidade Federal do Rio de Janeiro working in the field of oceanography. Including research on Dynamics of Cohesive Sediments, Environmental modeling, sediment transport, tidal propagation, hydrodynamic modeling, numerical modeling and fine sediments.

Allan Sandez de Oliveira. Graduated in Geography at Universidade do Estado do Rio de Janeiro, M.Sc. and currently a PhD student in Marine Geology and Geophysics from the Universidade Federal Fluminense and working in Environmental Geology and Climate Change and Global Events.

Michel Arthur Faria Vicente. Graduated in Geography at Universidade do Estado do Rio de Janeiro, M.Sc. and currently a PhD student in Marine Geology and Geophysics from the Universidade Federal Fluminense and working in Environmental Geology and Marine Geophysics.

Olaf Malm. Graduated in Biological Sciences from the Universidade Estadual de Campinas, M.Sc. and Ph.D. in Biological Sciences (Biophysics) from the Universidade Federal do Rio de Janeiro. Postdoc at the University of Southern Denmark in the Department of Environmental Medicine conducting research with emphasis in Environmental and Human Contamination by Heavy Metals and Persistent Organic micropollutants, working mainly in aquatic environments. Vice coordinator INCT Translational Research on Health and Environment in the Amazon Region (INPeTAm). Member of the Board of Ecology and Limnology CNPq. Professor, Head of the Laboratory of Radioisotopes Eduardo Penna Franca and former Director of the Institute of Biophysics Carlos Chagas Filho, UFRJ.

Cleverson Guizan Silva. B.Sc. and M.Sc. in Geology from Universidade Federal do Rio de Janeiro and a Ph.D. in Geology - Duke University, USA. Associate Professor, Universidade Federal Fluminense, acting in undergraduate degree in Geophysics. Editor-in-chief of the Brazilian Journal of Geophysics conducting research in marine geology and geophysics, with emphasis on coastal and marine depositional environments. 